\title{
FACTORS RELATED TO EMPLOYEE SATISFACTION IN THE HOSPITAL PUBLIC SERVICE AGENCY OF KONAWE DISTRICT
}

\author{
Alisia Witanti ${ }^{1}$, La Ode Saafi ${ }^{2}$, La Ode Kamalia ${ }^{3}$ \\ ${ }^{1,2,3}$ Magister of Public Health Study Program, Universitas Mandala Waluya \\ In Kendari, Southeast Sulawesi Province, Indonesia
}

Corresponding Author : Alisia Witanti

Email : aa.wita@yahoo.com

\section{Abstract}

Background:The increasing of number of patient visits every year and the ratio of bed usege must be comparable to satisfied employees. However, this has not been in line with the satisfaction felt by employees at the Konawe District Hospital. The purpose of this research is to learn factors related to employee satisfaction at the Regional Uum Service Agency Regional General Hospital, Konawe Regency Hospital.

Methods: The study was a quantitative study using a cross sectional study design.The population in this study were all employees at the Bombana District Hospital,namely 157 people. The number of samples in this study were 210 people. The sample was determined by simple random sampling technique. The data were processed using thechi square test.

Result: The results of the study using the chi square test show that management is significant towards employee satisfaction $\left(\mathrm{X}^{2}\right.$ cal. $.=33,925>\mathrm{X}^{2}$ tab $\left.=3,841\right)$, education and training are significant to employee satisfaction $\left(X^{2}\right.$ cal. $=39,230>X^{2}$ tab $=3,841$.

Conclusion: Management is related to employee satisfaction and education. training is also related to employee satisfaction at Konawe District Hospital. However, reward is not related to employee satisfaction.

Key words : Satisfaction, Management, Education, Training 


\section{INTRODUCTION}

General hospitals are usually facilities that are easily found in a country, with a very large hospitalization capacity for intensive or long-term care(1).Hospital is a health service provider institution that is an integral part of the health service system that provides curative and preventive services and provides outpatient and inpatient services as well as home care(2).

Satisfaction is the general attitude of an individual to the work he does. Someone with a high level of job satisfaction shows a positive attitude towards their job, while someone who is not satisfied with their job shows a negative attitude towards their job(3).

Satisfaction of health service providers is indeed very important, but that satisfaction is often overlooked or forgotten. Health care providers who are frustrated and disappointed or dissatisfied will be less productive and less efficient. Employee satisfaction in the long term will have an economic impact. Employee satisfaction gives direction to expectations, while audits will lead to work implementation instructions. Thus, the measurement of employee satisfaction is always seen in relation to expectations. Common aspects of employee satisfaction include organization and management, educational needs, rewards, incentives and promotions(4).

Based on data from the BLUD of Konawe District Hospital, the number of employees in 2017 was 612 people, in 2018 there were 618 people, in 2019 there were 604 people and in 2020 the period of February 2020 was 601 people (BLUD RS Kab. Konawe, 2019). With the large number of employees in the Konawe Regional Hospital, the RSUD should be able to provide satisfaction to all employees in carrying out their work at Konawe Hospital(5).

The results of further investigation by asking directly to the management of the Konawe Regional Hospital stated that in the Konawe Regional Hospital there had never been a direct employee job satisfaction assessment, only patient assessment. Whereas along with patient satisfaction, employee job satisfaction should also be an important concern for the manager of the Konawe District Hospital. Management revealed that employee satisfaction is very important for employees in carrying out their duties, functions and roles in the field of health services.

\section{METHOD}

This study used quantitative research methods using a cross sectional study design(6). This research was conducted from September 2 to October 2, 2020. The population in this study were all employees at the BLUD Konawe District Hospital in the Inpatient Unit, central surgery room, clinic clinic room, nutrition and emergency room totaling 441 people. sample size of 210 people. Determination of the sample using simple random sampling(7).

\section{RESULT}

Table 1 shows that out of 210 respondents, the largest number of respondents in the age group were those at the age of 32-39 years, amounting to 72 people $(34.3 \%)$ and the least being in the 48 55 years group with 38 people (18.1\%).

Table 2 shows that out of 210 respondents the highest number of respondents was female, amounting to 132 people $(62.9 \%)$ while male respondents were 78 respondents $(37.1 \%)$.

Table 3 shows that the statistical test results show that the value (X2hit $=33,925$ > $\mathrm{X} 2 \mathrm{tab}=3,841)$, it means that there is a relationship between management and employee satisfaction at the Regional Public Service Agency of the Konawe District Hospital. Furthermore, the results of the relationship closeness test show that the value $\varphi$ ie 0.412 or indicates a moderate relationship.

Table 4 shows the statistical test results show that the value (X2hit $=39,230$ ) $\mathrm{X} 2$ tab $=3,841)$, meaning that there is a 
Witanti, A., L.O. Saafi, \& L.O. Kamalia. DOI: 10.36566/ijhsrd/Vol3.Iss1/49

https://ijhsrd.com/index.php/ijhsrd

e- ISSN: $2715-4718$

relationship between education and training and employee satisfaction at the Regional Public Service Agency for the Konawe District Hospital. Furthermore, the results of the relationship closeness test show that the value $\varphi$ that is 0.442 or indicates a moderate relationship.

Table 5 show that the value $(\mathrm{X} 2$ hit $=$ $0.047<\mathrm{X} 2 \mathrm{tab}=3.841)$, means that there is

Table 1

Distribution of Respondents by Age Group at the Hospital BLUD Konawe District

\begin{tabular}{c|c|c|c}
\hline No. & $\begin{array}{c}\text { Age group } \\
\text { (Year) }\end{array}$ & $\mathrm{n}$ & $\%$ \\
\hline 1. & $24-31$ & 43 & 20.5 \\
2. & $32-39$ & 72 & 34.3 \\
3. & $40-47$ & 57 & 27.1 \\
4. & $48-55$ & 38 & 18.1 \\
\hline \multicolumn{2}{r|}{} \\
\hline
\end{tabular}

Table 2

Distribution of Respondents by Gender Group in BLUD

Konawe District Hospital

\begin{tabular}{|c|c|c|c|}
\hline No. & Gender & $\mathrm{n}$ & $\%$ \\
\hline 1. & Male & 78 & 37.1 \\
\hline 2. & Women & 132 & 62.9 \\
\hline \multicolumn{2}{|r|}{ Total } & 210 & 100 \\
\hline
\end{tabular}

Table 3

Distribution of Management According to Employee Satisfaction at the Regional Public Service Agency of the Konawe Regency Hospital

\begin{tabular}{|c|c|c|c|c|c|c|c|}
\hline \multirow{3}{*}{ Management } & \multicolumn{4}{|c|}{ Satisfaction } & \multirow{2}{*}{\multicolumn{2}{|c|}{ Amount }} & \multirow{2}{*}{ Statistic test } \\
\hline & \multicolumn{2}{|c|}{ Satisfied } & \multicolumn{2}{|c|}{ Less } & & & \\
\hline & $\mathrm{N}$ & $\%$ & $\mathrm{n}$ & $\%$ & $\mathrm{n}$ & $\%$ & \multirow{4}{*}{$\begin{array}{l}X 2 \text { hit }=33,230 \\
X 2 \mathrm{tab}=3,841 \\
\varphi=0.442\end{array}$} \\
\hline Good & 59 & 61.5 & 37 & 38.5 & 96 & 100 & \\
\hline Less & 24 & 21.1 & 90 & 78.9 & 114 & 100 & \\
\hline Total & 83 & 39.5 & 127 & 60.5 & 210 & 100 & \\
\hline
\end{tabular}


Table 4

Distribution of Training and Education according to Employee

Satisfaction in Service BodiesKonawe District General Hospital

\begin{tabular}{|c|c|c|c|c|c|c|c|}
\hline \multirow{3}{*}{ Training } & \multicolumn{4}{|c|}{ Satisfaction } & \multirow{2}{*}{\multicolumn{2}{|c|}{ Amount }} & \multirow{2}{*}{ Statistic test } \\
\hline & \multicolumn{2}{|c|}{ Satisfied } & \multicolumn{2}{|c|}{ Less } & & & \\
\hline & $\mathrm{n}$ & $\%$ & $\mathrm{~N}$ & $\%$ & $\mathrm{n}$ & $\%$ & \multirow{4}{*}{$\begin{array}{l}X 2 \text { hit }=39,230 \\
X 2 \text { tab }=3,841 \\
\varphi=0.412\end{array}$} \\
\hline Enough & 55 & 66.3 & 28 & 33.7 & 83 & 55 & \\
\hline Less & 28 & 22.0 & 99 & 78.0 & 127 & 28 & \\
\hline Total & 83 & 39.5 & 127 & 60.5 & 210 & 83 & \\
\hline
\end{tabular}

Table 5

Reward Distribution According to Employee Satisfaction in Service BodiesKonawe District General Hospital

\begin{tabular}{|c|c|c|c|c|c|c|c|}
\hline \multirow{3}{*}{ Rewards } & \multicolumn{4}{|c|}{ Satisfaction } & \multirow{2}{*}{\multicolumn{2}{|c|}{ Amount }} & \multirow{2}{*}{ Statistic test } \\
\hline & \multicolumn{2}{|c|}{ Satisfied } & \multicolumn{2}{|c|}{ Less } & & & \\
\hline & $\mathrm{n}$ & $\%$ & $\mathrm{~N}$ & $\%$ & $\mathrm{n}$ & $\%$ & \multirow{4}{*}{$\begin{array}{l}X 2 \text { hit }=0.047 \\
X 2 \text { tab }=3,841 \\
\varphi=0.025\end{array}$} \\
\hline Enough & 40 & 40.8 & 58 & 59.2 & 98 & 40 & \\
\hline Less & 43 & 38.4 & 69 & 61.6 & 112 & 43 & \\
\hline Total & 83 & 39.5 & 127 & 60.5 & 210 & 83 & \\
\hline
\end{tabular}

\section{DISCUSSION}

\section{Management Relationship with Employee Satisfaction}

Management as a typical process consisting of planning, directing and controlling actions carried out to determine and achieve predetermined goals through the use of human resources and other sources.(8).

The results showed that the hypothesis was accepted, meaning that there is a relationship between management and employee satisfaction at the Regional Public Service Agency for the Konawe District Hospital. Furthermore, the results of the relationship closeness test show that the value $\varphi$ ie 0.412 or indicates a moderate relationship. PThis study is in line with research conducted by (9)which states that the management function has a positive influence on member satisfaction in the organization, where performance is influenced by the level of employee job satisfaction of $72.50 \%$ in an industry.

Its application must be adjusted to the scope of organizational functions, the form of human cooperation that exists within the organization and the scope of the problems faced, in the health sector, management is applied to regulate the behavior of staff working within the health organization (service institution) to maintain and overcome health disorders in individuals. or community groups effectively, efficiently and productively(10).

\section{The Relationship between Training and Quality of Human Resources}

Good governance (Good Govermence), it is absolutely necessary to have qualified, tested and professional good government apparatus, including police institutions, need to pay attention to its human resources(11).

The results showed that the hypothesis was accepted. means thatthere is a relationship between education and training with employee satisfaction at the Regional Public Service Agency for the Konawe District Hospital. Furthermore, the results of the relationship closeness test show that the value $\varphi$ that is 0.442 or indicates a moderate relationship. The results of this study are 
supported by research (12), which states that training has a significant effect on job satisfaction. Based on the results of the discussion, every education and training is carried out, will be able to increase job satisfaction. The more often education and training are carried out, the higher the level of job satisfaction(13).

According to Notoadmodjo, defining education and training is an effort to develop human resources, especially to develop intellectual abilities and human personality in education and training programs for employees. We often hear training and development in the world of work in companies, organizations, institutions, or even in health agencies. It can be assumed that training and development are very important for the workforce to work more masterfully and better at the job that is currently held or will be held in the future. Not too far from government agencies, training and development are often carried out as an effort to improve the performance of employees who are deemed incapable of carrying out their duties due to the development of community needs in terms of services(14).

Training can be viewed as a form of investment. Therefore, every organization or agency that wants to develop, training for its employees must receive great attention(15). This is important because of the methods used by the organization to maintain, maintain, maintain public employees in the organization and at the same time improve the skills of employees so that they can improve their performance. The provision of education and training is one of the efforts to improve the quality of human resources according to job requirements. In order to improve human resources in each work unit, it will also be related to the nature of education and training.

\section{The Relationship between reward and Employee Satisfaction}

Reward is something that is received by workers as an addition or substitute for contributions that exceed their responsibility to the company(16). Rewarding consists of the desired reward and the expected reward, both extrinsic and intrinsic. Perceived rewards are evaluative assessments in the form of financial and non-financial benefits received by workers as a result of their performance with the company(17).

The results showed that the hypothesis was accepted. means thatthere is no relationship between reward and employee satisfaction at the Regional Public Service Agency for the Konawe District Hospital. Furthermore, the results of the relationship closeness test show that the value $\varphi$ that is 0.025 or indicates a very weak relationship.

The results of hypothesis 1 testing indicate that reward does not have a significant effect on employee job satisfaction at PT Bank Central Asia Tbk. Surakarta Main Branch. The findings of this study are not in line with the results of research conducted by (18), that reward has a significant effect on employee job satisfaction. The inconsistency of the findings of this study is due to the different attitudes and behaviors of employees from each organization or company.

The implication of these findings is that the rewards given by the company can not directly affect employee job satisfaction, because the forms of rewards desired by employees are very diverse. The form of reward that employees want is not only in the form of extrinsic rewards such as salary, allowances, but also intrinsic rewards such as task completion, achievement, autonomy (independence), and personal development(19). For example, the results of the questionnaire show that employees disagree on task completion indicators. This response illustrates that the supervisor's trust in fostering a sense of employee involvement in completing tasks with full responsibility is lacking(20).

Indonesian Journal Of Health Sciences Research and Development 


\section{CONCLUSION}

There is a relationship between management and employee satisfaction at the Regional Public Service Agency at the Konawe Regency Hospital, There is a relationship between education and training and employee satisfaction at the Regional Public Service Agency at the Konawe Regency Hospital, There is no relationship between reward and employee satisfaction at the Regional Public Service Agency of the Hospital Konawe District Hospital. The RSUD KabupatenKonawe needs to pay attention to the problem of giving rewards, incentives, and the division of tasks so that it is in line with employee expectations in order to increase job satisfaction and prevent employees who are absent from their work.

\section{REFERENCES}

1. Rungta N, Zirpe KG, Dixit SB, Mehta Y, Chaudhry D, Govil D, et al. Indian society of critical care medicine experts committee consensus statement on ICU planning and designing, 2020. Indian journal of critical care medicine: peerreviewed, official publication of Indian Society of Critical Care Medicine. 2020; 24 (Suppl 1): S43.

2. Aditama. Hospital Administration Management. Jakarta: UI-Pfress; 2007.

3. Nursalam. Nursing Management: Applications in Professional Nursing Practice Jakarta: Salemba Medika; 2012.

4. Pohan. Health Service Quality Assurance. Jakarta: EGC; 2017.

5. Konawe RK. Health Profile of the Konawe District General Hospital. Unaaha: Konawe Hospital Education and Training; 2019.

6. Mackey A, Gass SM. Second language research: Methodology and design: Routledge; 2015.

7. Sugiyono PD. Qualitative and Quantitative Research Methods R \& D. Bandung: Alfabeta; 2011.
8. Hasibuan M. Human Resource Management. Jakarta: Earth Literacy; 2009.

9. Ridho M, Susanti F. Effect of Job Stress and Work Motivation on Job Satisfaction of Employees of Bank Mandiri Syariah Branch of Padang. 2019.

10. Muninjaya PDAAG. Health Management Ed. 3. Jakarta: EGC Medical Book Publisher; 2015.

11. Hertati D, Arif L. Development of a Web-Based Quality Public Service Model in the Sidoarjo Regency Government District. Publisher Cakradewa Ilmu. 2020; 1.

12. Syahputra I, Jufrizen J. The Influence of Training, Promotion, and Job Satisfaction on Employee Performance. Maneggio: Scientific Journal of Master of Management. 2019; 2 (1): 104-16.

13. Marjaya I, Pasaribu F. The Influence of Leadership, Motivation, and Training on Employee Performance. Maneggio: Scientific Journal of Master of Management. 2019; 2 (1): 129-47.

14. Notoatmodjo S. Health research methodology. Jakarta: inventions; 2010.

15. Irmatasari D. Influence of Education and Training (Diklat) and work ability on Employee Performance at Tampan Mental Hospital Pekanbaru: State Islamic University Sultan Syarif Kasim Riau; 2019.

16. Hidayatullah S. The Effect of Job Satisfaction and Compensation on Employee Performance at the Regional Company Offices of the Indonesian Electrical Professionalist Association (PD APEI Aceh) 2020.

17. Sheikh N. Organizational rewards and employee commitment: a Chinese study. Journal of Managerial Psychology. 2012; 27 (1): 71-89.

18. Maarif M. Effect of Motivation, Job Promotion and Compensation on Employee Performance with Job Satisfaction as an Intervening Variable 
Witanti, A., L.O. Saafi, \& L.O. Kamalia. DOI: 10.36566/ijhsrd/Vol3.Iss1/49

https://ijhsrd.com/index.php/ijhsrd

(study at BPRS Artha Surya Barokah Semarang): IAIN SALATIGA; 2020.

19. Qhotimah SC. Effect of Workload, Work Motivation, Work Environment and Rewards on Employee Performance of Rural Banks (BPR) in Kediri: STIE Perbanas Surabaya; 2019.

20. Pandoyo DB, Lantara I, Nugroho MAS. Efforts to Improve Member Performance in terms of Motivation and Democratic Leadership Style in the Police Sector Dukun Magelang: STIE Widya Wiwaha; 2019. 